\title{
Preliminary results on the effect of the inclusion of cottonseed oilcake meal on the feed intake and growth of slaughter ostriches (Struthio camelus var. domesticus)
}

\author{
T.S. Brand ${ }^{1,2 \#}$, D. Squizzato ${ }^{3}$, L.C. Hoffman ${ }^{2}$ \& A. Dalle Zotte ${ }^{3}$ \\ ${ }^{1}$ Elsenburg Institute for Animal Production, Western Cape, Department of Agriculture, Private Bag X1, \\ Elsenburg 7606, South Africa; ${ }^{2}$ University of Stellenbosch, Department of Animal Sciences, Private Bag X1, \\ Matieland, 7602, South Africa; ${ }^{3}$ Department of Animal Medicine, Production and Health, University of Padova, \\ Agripolis, Viale dell'Universita 16, 35020, Legnaro, Italy
}

Copyright resides with the authors in terms of the Creative Commons Attribution 2.5 South African Licence.
See: http://creativecommons.org/licenses/by/2.5/za/
Condition of use: The user may copy, distribute, transmit and adapt the work, but must recognise the authors and the South African Journal
of Animal Science

\begin{abstract}
The ostrich (Struthio camelus var. domesticus) is an important animal in the livestock industry in South Africa. Ostrich production is an intensive production system and feed cost contributes approximately $75 \%$ of the total cost of production. The objective of this study was to determine the effect of the replacement of soybean oilcake meal (SOCM) with cottonseed oilcake meal (CSOCM) on the production performance of slaughter ostriches. A total of 105 birds of both sexes were divided into five groups of 21 birds each. All birds were fed five iso-nutritional diets in which SOCM was gradually replaced by CSOCM ( $0 \%$ up to $12 \%$ of the total diet). Ostriches in each treatment were subdivided into three replicate pens containing seven birds each. Body weights of birds were recorded at the start of the experiment and thereafter on a monthly basis throughout the study. Inclusion level of CSOCM had no effect on the feed intake and feed conversion rate of slaughter ostriches. Birds consuming the diet with 0\% CSOCM had a significantly lower growth rate than the birds consuming the diets containing respectively $9 \%$ and $12 \%$ CSOCM. In a complementary palatability study, no significant differences in feed intake were observed between the diets with and without CSOCM.
\end{abstract}

Keywords: Cottonseed oilcake meal, feed intake, growth, ostriches

\#Corresponding author: tersb@elsenburg.com

\section{Introduction}

Ostrich farming is an important component of the agribusiness industry in South Africa. Ostrich farming is an intensive farming system and the cost of feed contributes more than $75 \%$ of the total cost of production (Brand \& Gous, 2006). Soybean oilcake meal is normally used as a protein source in the diet of ostriches. Soybean oilcake meal is, however, also used in the poultry industry, and normally maintains relatively high prices. Cottonseed oilcake meal is also a rich source of high protein and can be incorporated in the diets of animals. Its value as an animal feed, however, is limited due to the presence of gossypol, which is a toxic polyphenolic pigment contained in glands located throughout the cottonseed plant. The content of gossypol in whole cottonseed ranges from $0.02 \%$ to $6.64 \%$ and is thought to provide resistance to insects (Prince et al., 1993). With the extraction of $21 \%$ oil from cottonseed, the gossypol content in CSOCM may vary from $0.03 \%$ to $8.4 \%$. This terpenoid inhibits $\alpha$-amylase of insects, one of the most important insect digestive enzymes (Franko et al., 2002). Many factors influence gossypol content such as species of cotton plant, climatic conditions, soil conditions and application of fertilizer. Although CSOCM has long been recognised as an economical protein source for ruminant diets, it may be potentially toxic when fed to monogastric animals at levels from $100-300 \mathrm{mg} / \mathrm{kg}$, respectively for pigs and poultry (Ensminger et al., 1990). 
Gossypol exists in two forms: free and bound. The free form is toxic, whereas gossypol that binds to proteins is the bound or non-toxic form. Cottonseed oilcake is the residue after oil is extracted from the seeds. Gossypol primarily affects the heart and liver. Ruminants such as cattle and sheep can tolerate higher levels of free gossypol because gossypol is detoxified in the rumen either by bonds formed with soluble proteins or by a dilution effect, which results in slower absorption of gossypol.

Dairy cows tolerate up to $6.2 \mathrm{mg} / \mathrm{kg}$ body weight free gossypol per day for 100 days (Lindsey et al., 1980). Lambs fed a diet containing $900 \mathrm{mg} / \mathrm{kg}$ of free gossypol for $3-4$ weeks died suddenly or after exhibiting signs of cardiac failure (Morgan et al., 1988). In pigs, dietary levels of $200-300 \mathrm{mg} / \mathrm{kg}$ of free gossypol results in cardiac insufficiency and respiratory distress with normal mortality rates exceeding 50\% (Haschek et al., 1989). In dogs, cardio toxicity associated with prolonged gossypol intake is similar to that in other species (Patton et al., 1985). Chicks fed 800 and $1600 \mathrm{mg} / \mathrm{kg}$ of purified gossypol in feed exhibited severe cases of perivascular lymphoid aggregate formation, biliary hyperplasia, and hepatic cholestasis (Henry et al., 2001). In fish, pathological effects of gossypol in tilapia were a decline in body weight, low haemoglobin and haematocrit levels, abundance of immature red blood and abnormal spleen morphology (Garcia Abiado et al., 2004).

Although CSOCM has been shown to negatively affect different mammalian species, such as pigs, goats, pre-ruminant calves and lambs, dogs, as well as chicks and fish, its effects on ostriches have not yet been studied. The aim of the study was thus to determine the effect of a low inclusion level of CSOCM in diets of growing ostriches on their feed intake and growth performance. A study was also conducted to determine the palatability of diets containing CSOCM in comparison to SBOCM.

\section{Materials and Methods}

A total of 105 ostriches (Struthio camelus var. domesticus), approximately 6 months of age, were used in the study. The study was conducted at the Kromme Rhee Research Farm near Stellenbosch. The birds were divided into five groups, which were subdivided into three replicate pens (ca $200 \mathrm{~m}^{2} / \mathrm{bird}$ ). Diets were formulated on an iso-nutritional basis in a way that SBOCM was gradually replaced by CSOCM (Table 1). Experimental diets were fed ad libitum.

Table 1 The physical composition of ostrich finisher diets in which soybean oilcake meal (SBOCM) was replaced step-wise by cottonseed oilcake meal (CSOCM)

\begin{tabular}{lccccc}
\hline \multirow{2}{*}{$\begin{array}{l}\text { Feed ingredient } \\
\mathrm{kg})\end{array}$} & 0 & 3 & 6 & 9 & 12 \\
\cline { 2 - 5 } & 45.38 & 41.66 & 37.93 & 34.21 & 30.48 \\
\hline Lucerne meal & 37.83 & 37.83 & 37.83 & 37.83 & 37.83 \\
Yellow maize & 0 & 3.00 & 6.00 & 9.00 & 12.00 \\
CSOCM & 0 & 2.96 & 5.91 & 8.87 & 11.83 \\
Wheaten bran & 10.00 & 7.50 & 5.00 & 2.50 & 0 \\
Soybean oilcake meal & 2.50 & 2.50 & 2.50 & 2.50 & 2.50 \\
Molasses powder & 1.63 & 1.69 & 1.74 & 1.80 & 1.85 \\
Limestone, ground & 1.05 & 1.24 & 1.42 & 1.61 & 1.79 \\
MCP. & 1.00 & 1.00 & 1.00 & 1.00 & 1.00 \\
Fine salt & 0.50 & 0.50 & 0.50 & 0.50 & 0.50 \\
Vit \& min premix & 0.10 & 0.10 & 0.09 & 0.08 & 0.08 \\
DL-methionine 40\% & 0 & 0.03 & 0.06 & 0.10 & 0.13 \\
L-lysine 95\% & & & & & \\
\hline
\end{tabular}


All birds were allowed free access to drinking water. Animal body weights were recorded on monthly intervals from the start of the experiments up to 12 months of age at slaughter. The feed conversion rate was calculated using average feed intake and average weight gain per group.

Ostriches were slaughtered at a commercial abattoir and dressed according to standard South African techniques. High performance liquid chromatography (HPLC) procedures have been used to measure free, bound and total gossypol in the CSOCM and free gossypol in the mixed feed (AOCS, 1989).

A complementary trial of five days was conducted to determine the palatability of the five different diets containing increased levels of CSOCM. A total of 33 ostriches of both sexes (22 males and 11 females) aged 13 months, were divided into three replicate pens. Each animal was given free access/choice to the five experimental diets. The refusal of each diet was weighed daily and ration consumed were recorded to estimate relative palatability.

The data obtained was analysed using analysis of variance technique under one-way ANOVA with the GenStat software package (Release 7.2 DE, 2007) and Student's t-Least Significant Difference was determined at 5\% significant level to compare treatment means (Ott, 1998).

\section{Results and Discussion}

Diets were formulated to provide equal amounts of energy, protein as well as essential amino acids to the birds. Chemical analysis of the experimental diets showed a free gossypol content below $10 \mathrm{mg} / \mathrm{kg}$. Chemical analysis of the CSOCM showed a value of $82 \mathrm{mg} / \mathrm{kg}$ of free gossypol, $4790 \mathrm{mg} / \mathrm{kg}$ of chemically bound gossypol and $4872 \mathrm{mg} / \mathrm{kg}$ of total gossypol.

Production results are presented in Table 2 . The starting weight of the birds in the different treatment groups did not differ significantly between groups $(P>0.05)$.

Table 2 Average ( \pm SE) daily weight gain (ADG), feed intake and feed conversion ratio (FCR) of ostriches consuming diets containing increasing levels of cotton seed oil cake meal (CSOCM) replacing soy bean oil cake meal

\begin{tabular}{lccccc}
\hline & \multicolumn{5}{c}{ CSOCM inclusion level (\%) } \\
\cline { 2 - 6 } Parameters & 0 & 3 & 6 & 9 & 12 \\
\hline ADG (g/bird/day) & $219^{\mathrm{b}} \pm 21$ & $248^{\mathrm{ab}} \pm 10$ & $266^{\mathrm{ab}} \pm 19$ & $277^{\mathrm{a}} \pm 9$ & $287^{\mathrm{a}} \pm 12$ \\
Feed Intake (kg/bird/day) & $1.775^{\mathrm{a}} \pm 0.052$ & $1.915^{\mathrm{a}} \pm 0.153$ & $1.867^{\mathrm{a}} \pm 0.044$ & $1.917^{\mathrm{a}} \pm 0.076$ & $1.927^{\mathrm{a}} \pm 0.110$ \\
FCR (kg feed/weight gain) & $8.47^{\mathrm{a}} \pm 0.554$ & $7.53^{\mathrm{a}} \pm 0.608$ & $8.13^{\mathrm{a}} \pm 0.986$ & $7.45^{\mathrm{a}} \pm 0.427$ & $7.40^{\mathrm{a}} \pm 0.574$ \\
\hline
\end{tabular}

${ }^{\mathrm{a}, \mathrm{b}}$ Means within rows with different superscripts differ significantly $(P<0.05)$.

The feed intake of ostriches was not affected $(P>0.05)$ by the inclusion level of CSOCM in diets. Birds consuming diets with $9 \%$ and $12 \%$ CSOCM had a faster $(P<0.05)$ growth rate than birds consuming the diet with $0 \%$ CSOCM. Regression analysis of the data revealed that growth rate of birds increased with $5.5 \mathrm{~g} /$ day for each increment increase in the CSOCM content of the diets $\left(\mathrm{y}=226.4+5.5 \mathrm{y} ; \mathrm{R}^{2}=0.97\right)$. Similarly to feed intake, feed conversion ratios did not differ $(P>0.05)$ between experimental diets. Data from the palatability trial (feed intake of respectively 594, 515, 466, 501 and $662 \mathrm{~g} / \mathrm{bird} /$ day for diets containing $0 \%, 3 \%, 6 \%, 9 \%$ and $12 \%$ CSOCM) showed the highest feed intake value from the diet containing $12 \%$ CSOCM, but no specific pattern in feed intake between diets was observed. The results clearly indicated that birds did not discriminate against diets containing higher levels of CSOCM. Results from this study is in contradiction to the recommendations from Aganga et al. (2003), who recommend that CSOCM should not be used at all in diets for ostriches. This assumption may be related to scientific results obtained with other monogastric species. 


\section{Conclusion}

Cottonseed oilcake has been used for many years as a protein supplement in ruminant rations, but due to the presence of gossypol, its use in the diets of monogastric animals has been limited. Results from this study clearly showed that CSOCM up to $12 \%$ can be used with success in diets for finishing ostriches. A palatability trial showed that birds did not discriminate against diets containing CSOCM up to 12\%. A veterinary inspection of the hearts and livers of the birds consuming diets containing CSOCM showed no cardiovascular or other damage; it may thus be suggested that the gossypol content of CSOCM should be tested prior to inclusion as protein source in diets of ostriches. Safety margins of $0.03 \%(300 \mathrm{mg} / \mathrm{kg})$ free gossypol in diets as suggested for poultry by Ensminger et al. (1990) should be respected. Results from this study are only applicable to growing ostriches and not to breeding birds for which scientific data is still lacking.

\section{References}

Aganga, A.A., Aganga, A.O. \& Omphile, U.J., 2003. Ostrich feeding and nutrition. Pakistan J. Nutr. 2, 60-67.

A.O.C.S., 1989. Free and Total Gossypol Methods, Official and Tentative Methods of the AOCS. 4th Ed. Chicago: American Oil Chemists' Society.

Brand, T.S. \& Gous R.M., 2006. Feeding ostriches. In: Feeding Domestic Vertebrates. Ed. V. Bells. CABI, London.

Ensminger, M.E., Oldfield, J.E. \& Heinemann, W.W., 1990. Feeds and Nutrition. The Ensminger Publishing Company, California, USA.

Franko, O.L., Rigden, D.J., Melo, F.R. \& Grossi-de-Sa, M.F., 2002. Plant alpha-amylase inhibitors and their interaction with insect alpha-amylases. Eur. J. Biochem. 397-412.

Garcia-Abiado, M.A., Mbahinzireki, G., Rinchard, J., Lee, K.J. \& Dabrowski, K., 2004. Effect of diets containing gossypol on blood parameters and spleen structure in tilapia, Oreochromis sp., reared in a recirculating system. J. Fish Dis. 27, 359-368.

GenStat 2007. Release 7.2 DE Copyright 2007, Lawes Agricultural Trust (Rothamsted Experimental Station).

Haschek, W.M., Beasley, V.R., Buck, W.B. \& Finnell, J.H., 1989. Cottonseed meal (gossypol) toxicosis in a swine herd. J. Am. Vet. Assoc. 195, 613-615.

Henry, M.H., Pesti, G.M. \& Brown, T.P., 2001. Pathology and histopathology of gossypol toxicity in boiler chicks. Avian Dis. 45, 598-604.

Lindsey, T.O., Hawkins, G.E. \& Guthrie, L.D., 1980. Physiological responses of lactating cows to gossypol from cottonseed meal rations. J. Dairy Sci. 63, 562-573.

Morgan, S., Stair, E.L, Martin, T., Edwards, W.C. \& Morgan, G.L., 1988. Clinical, clinic pathologic, and toxicological alterations associated with gossypol toxicosis in feeder lambs. Am. J. Vet. Res. 49, 493-499.

Ott, R.L., 1998. An Introduction to Statistical Methods and Data Analysis. Duxbury Press, Belmont, California, USA.

Patton, C.S., Legendre, A.M., Gompf, R.E. \& Walker, M.A., 1985. Heart failure caused by gossypol poisoning in two dogs. J. Am. Vet. Med. Assoc. 187, 625-627.

Prince, W.D., Lovell, R.A. \& McChesney, D.G., 1993. Naturally occurring toxins in feedstuffs: Center for Veterinary Medicine Perspective. J. Anim. Sci. 71, 2556-2562. 